\title{
ANALEK DAN PENERAPANNYA DALAM PENDIDIKAN DI PERGURUAN TINGGI
}

\author{
Yohan Yusuf Arifin \\ D3 Bahasa Mandarin, Fakultas Bahasa dan Budaya \\ Universitas Kristen Maranatha, Bandung
}

\begin{abstract}
Abstrak
Analek merupakan sebuah buku berisi tentang percakapan antara Konfusius selama masa hidupnya dengan murid-muridnya. Buku ini merupakan salah satu karya yang cukup penting bagi orang-orang yang mempelajari ajaran Konfusianisme. Di dalamnya tidak hanya terdapat ajaran-ajaran moral tentang hubungan antar manusia tetapi juga terkandung ajaran-ajaran yang berkaitan dengan bidang pendidikan, politik, tata negara, dIl.

Penelitian ini mencoba untuk membahas isi dari ajaran dalam buku Analek yang ada kaitannya dengan pendidikan, khususnya cara pengajaran yang dibahas di dalamnya.

Penelitian ini merupakan penelitian deskriptif kualitatif dengan menggunakan Analek sebagai bahan acuannya ditunjang dengan menggunakan literatur-literatur lainnya yang ada kaitannya dengan pengajaran dalam Kofusianisme.

Diharapkan hasil penelitian ini dapat memberikan referensi tambahan yang bermanfaat bagi dunia pendidikan perguruan tinggi di Indonesia dan referensi bagi penelitian yang sejenis.
\end{abstract}

Kata Kunci: Analek, Konfusianisme, pengajaran, perguruan tinggi

\begin{abstract}
Analect is a book about conversations between Confucius during his lifetime with his students. This book is one of the important references for people who study Confucianism. There are not only moral theories about human relations but also contained many theories relating to education, politics, state administration, etc.

This research tries to discuss the contents of the teachings in the book Analect which has to do with education, specifically the way of teaching.

This research is a qualitative descriptive study using the Analect as a reference material supported by using other literature that has connection with teaching in Cofusianism.

The results of this study are expected to provide additional references that are useful for education in Indonesia and references for similar research.
\end{abstract}

Keywords: Analect, Confucianism, teaching, college

\section{A. PENDAHULUAN}

\section{1) Latar Belakang}

Kurikulum Kerangka Kualifikasi Nasional Indonesia (KKNI) adalah kurikulum yang diterapkan dalam pendidikan perguruan tinggi. Kurikulum ini didesain dan diterapkan di perguruan tinggi dengan memuat berbagai kompetensi yang dapat dijadikan bekal oleh setiap lulusan agar mereka nantinya siap masuk ke dalam dunia kerja. Kurikulum ini lebih menitikberatkan kepada pembelajaran student learning center, di mana melalui kurikulum ini, mahasiswa menjadi pusat pembelajarannya, dan mahasiswa dituntut untuk lebih aktif lagi dalam setiap aktivitas perkuliahan. Dosen tidak lagi dituntut untuk berbicara terusmenerus di depan kelas, tetapi diharapkan dapat lebih membimbing dan mengarahkan mahasiswa dalam mempraktikkan setiap ilmu yang dipelajarinya. 
Di era globalisasi saat ini, perguruan tinggi dituntut untuk dapat menghasilkan lulusan yang tidak hanya memiliki nilai yang baik dari sisi akademiknya saja, tetapi juga harus dibekali kemampuan lainnya yang dapat menjadi nilai lebih bagi setiap lulusan ketika mereka masuk di dunia kerja. Akan tetapi pada kenyataannya tidak sedikit juga lulusan yang telah lulus tidak dapat bekerja dengan baik di tempat kerjanya, sehingga memberikan persepsi yang kurang baik bahwa perguruan tinggi tidak berhasil dalam membina mahasiswanya, padahal dengan diterapkannya pembelajaran student learning center seharusnya mahasiswa dapat lebih baik lagi dalam mengaplikasikan hal-hal yang didapatkannya selama di perguruan tinggi.

Permasalahan yang ada di atas sebenarnya dapat diakibatkan oleh berbagai faktor penyebab yang perlu dicari solusinya masing-masing. Penulis merasa bahwa perlu ada perbaikan dalam sistem pendidikan perguruan tinggi kita, salah satunya dalam pengajaran yang diterapkan di dalamnya. Penulis mencoba mencari relevansi dari teori-teori tentang pengajaran yang terdapat dalam buku Analek untuk diterapkan dalam pengajaran perguruan tinggi pada saat ini.

Konfusius sendiri merupakan seorang ahli filsafat, guru, politikus yang handal pada masanya. Semasa hidupnya Konfusius banyak melahirkan pemikiran-pemikiran cemerlang yang dapat diterapkan dalam kehidupan sehari-hari. Buku Analek dipilih karena isinya banyak mengulas tentang nilai moral yang diajarkan oleh Konfusius. Selain dari ajaran moral, buku ini juga membahas mengenai pengajaran yang diterapkan oleh Konfusius pada masa itu. Sampai saat ini, pemikiran Konfusius tentang pengajaran masih relevan untuk digunakan, bahkan di China pun masih menggunakan pemikiran Konfusius untuk dipakai dalam pendidikan untuk sekolah-sekolah yang ada di sana.

Oleh karena itu, penulis merasa Analek dan pemikiran Konfusius tersebut dapat dijadikan bahan referensi untuk penelitian ini.

\section{2) Perumusan Masalah}

1. Apa saja pengajaran yang terdapat dalam buku Analek?

2. Bagaimana penerapan pengajaran tersebut dalam dunia pendidikan?

\section{3) Tujuan dan Manfaat Penelitian}

Hasil yang ingin dicapai dari penelitian ini diharapkan dapat memberikan solusi pemecahan dari masalah yang telah disebutkan di atas serta dapat menjadi bahan referensi bagi penelitian terkait.

Dari hasil pembahasan tersebut dapat diketahui hal-hal yang dapat dijadikan sebagai bahan acuan untuk pengajaran di perguruan tinggi, sehingga jika nantinya memang ada kekurangan dapat diperbaiki ke arah yang lebih baik lagi.

\section{4) Kerangka Pemikiran}

1. Tahap awal dari penelitian ini adalah menelaah dan mencari teori-teori dalam buku Analek dan referensi lainnya yang ada kaitannya dengan pengajaran.

2. Tahap kedua adalah melakukan analisis tersebut sambil mengaitkannya dengan masalah yang ada.

3. Tahap ketiga adalah melakukan pembahasan antara teori dengan data yang ada.

4. Tahap terakhir adalah menarik kesimpulan dari pembahasan yang telah dilakukan. 


\section{B. KAJIAN TEORI}

Penulis menggunakan isi dari buku Analek yang menjadi fokus dari penelitian ini yaitu tentang teori pengajaran Konfusius, lalu ditelaah dengan bahan refensi lainnya untuk diambil simpulan tentang maksud yang ingin disampaikan daripada teori pengajaran Konfusius tersebut, kemudian akan diaplikasikan dalam pola pengajaran yang ada di perguruan tinggi. Analek sendiri terdiri dari 20 bab yang berisi tentang kutipan percakapan antara Konfusius dengan muridmuridnya yang dibukukan oleh mereka setelah Konfusius meninggal dunia. Di dalamnya banyak terdapat banyak ajaran moral yang masih layak untuk diterapkan dalam kehidupan saat ini.

\section{METODE PENELITIAN}

Penulis dalam melaksanakan penelitian ini memakai metode penelitian pendekatan ilmiah yang menggunakan pola pemaparan deskriptif, yaitu penelitian yang dimulai dari keterangan atau pendapat dari teori tertentu dengan melakukan survei literatur/studi kepustakaan yang diperoleh dari artikel ilmiah, buku teks dan laporan penelitian sebagai data penunjang ${ }^{1}$, setelah itu dilakukan pendalaman untuk mendapatkan kesimpulan dari setiap pembahasan yang telah dijelaskan.

\section{PEMBAHASAN}

Di dalam buku Analek sendiri terdapat cukup banyak kutipan yang berisikan tentang pengajaran, akan tetapi pada penelitian ini, penulis hanya akan menggunakan kutipankutipan yang sekiranya relevan dan dapat diterapkan untuk permasalahan yang sedang diteliti penulis.

Minat seorang murid terhadap suatu hal bisa menjadi guru yang baik bagi perkembangannya dalam mempelajari sesuatu, karena dari minat ini mereka bisa mengerjakan semuanya itu dengan serius, seperti kutipan berikut ini,

$$
\begin{aligned}
& \text { 子日: “知之者不如好之者, 好之者不如乐之者。--《论语・雍也》 } \\
& \text { ZǏ yuē: “zhī zhī zhě bù rú hào zhī zhě, hào zhī zhě bù rú lè zhī zhě. 《Lúnyǔ • Yōng Yě 》 }
\end{aligned}
$$

Pengajar yang baik tentunya harus memiliki cara untuk terus menggali dan memupuk minat para muridnya untuk bisa berkembang dengan lebih baik lagi, karena dari minat tersebut mereka akan sangat mudah dibimbing dan diarahkan. Dari minat inilah seorang murid yang mungkin awalnya pasif dalam pembelajaran, akan menjadi aktif karena murid tersebut menyenangi hal yang dipelajarinya, sehingga efektifitas dari pembelajaran dapat lebih dirasakan olehnya. Dalam memupuk minat ini, kita dapat menggunakan berbagai cara metode pembelajaran yang menarik, tidak lagi menggunakan metode pembelajaran yang monoton. Kita dapat membuat metode pembelajaran yang lebih aplikatif dengan mengarahkan murid kita untuk mempraktikan apa yang telah mereka pelajari, sehingga mereka menyadari apa yang mereka pelajari dapat berguna ketika mereka bekerja nanti.

Setelah mengetahui minat dari setiap murid, Konfusius sangat menekankan akan pentingnya murid untuk memiliki karakter yang baik dalam mempelajari sesuatu,

子贡问日: “孔文子何以谓之'文”也? ”子日: “敏而好学, 不耻下文, 是以谓 之'文'也。

\footnotetext{
${ }^{1}$ Rosida Tiurma Manurung: Teknik Penulisan Karya Ilmiah, Bandung: Jendela Mas Pustaka, 2009, hal. 77.
} 
Ž̌gòng wèn yuē: "Kǒng wén zǐ hé yǐ wèi zhī wén yě?" Zǐ yuē: " mǐn ér hào xué, bù chǐ xià wén, shì yǐ wèi zhī wén yě.

Dalam kutipan di atas dijelaskan bahwa kriteria baik yang harus dimiliki seseorang yang berilmu adalah memiliki ketertarikan akan ilmu pengetahuan, memiliki inovasi yang tinggi dan memiliki kerendahan hati untuk bertanya. Sebagai pendidik kita harus dapat mendidik murid kita agar dapat memiliki karakter yang disebutkan di atas, karena jika tidak, setiap hal yang mereka pelajari akan menjadi sia-sia.

$$
\begin{aligned}
& \text { 子绝四-—册意, 册必, 册固, 册我。《论语・子罕》 } \\
& \text { Zǐ jué sì - - wú yì, wú bì, wú gù, wú wǒ. 《Lúnyǔ • Zǐ Hăn》 }
\end{aligned}
$$

Dalam kutipan ini, Konfusius ingin mengajarkan bahwa dalam proses menuntut ilmu sebagai pengajar kita harus dapat mengajarkan empat sikap di atas kepada murid kita. Sikap pertama adalah dalam menuntut ilmu kita harus dapat menggunakan sumber yang benar dan terpercaya, sikap kedua adalah melihat sesuatu secara objektif untuk mengambil kesimpulan dengan tepat, sikap ketiga adalah bersedia menerima saran dan kritik dari orang lain, sikap yang keempat adalah untuk selalu bersikap rendah hati dalam menuntut ilmu. Keempat sikap ini dipandang cukup penting karena tanpa sikap yang demikian mustahil bagi seorang murid untuk belajar dengan baik. Dari dua penjelasan di atas dapat dilihat Konfusius sangat mementingkan pembentukan karakter seorang murid dalam menuntut ilmu.

Dalam mendidik murid-muridnya Konfusius sangat menekankan dalam pola pikir yang kritis terhadap suatu permasalahan hal ini terlihat dalam kutipan:

$$
\text { 子曰:“学而不思则罔, 思而不学则殆。”- - 《论语・为政》 }
$$

Zì yuē: "xué ér bù sĩ zé wăng, sī ér bù xué zé dài." - - 《Lúnyǔ • Wéi Zhèng》

yang berarti dalam mempelajari sesuatu jika kita tidak menggunakan akal budi kita untuk menganalisisnya lebih dalam lagi maka apa yang kita pelajari tersebut akan menjadi sia-sia. Selain itu, menganalisis sesuatu secara mendalam dapat menghindarkan kita dari penafsiran yang salah dari permasalahan yang akan kita pecahkan. Melihat dari penjabaran di atas, sebenarnya kita bisa menerapkannya ke dalam pola pendidikan yang ada di sini. Sebagai pengajar sebaiknya kita mendidik murid kita untuk berpikir secara kritis dan mendalam, karena ada kalanya kita terkadang melupakan prinsip yang disebutkan di atas. Untuk mempermudah murid kita dalam memahami materi, kita terkadang secara menyeluruh memberikan materi yang harus mereka kuasai tanpa disertai hal-hal yang mengharuskan mereka untuk berpikir lebih lanjut. Mendidik murid kita untuk memiliki pola pikir kritis ini memegang peranan penting bagi mereka ketika mereka terjun ke dalam dunia kerja, karena dengan memiliki pola pikir kritis akan membantu mereka dalam mengaplikasikan setiap teori yang telah kita ajarkan dengan baik dan benar dan memecahkan setiap persoalan yang mereka hadapi.

$$
\text { 博学而笉志，切问而近思”- - 《论语・子张》 }
$$

bóxué ér dǔ zhī, qiē wèn ér jìn sī" 
Melalui kutipan ini, Konfusius berharap agar para muridnya menanyakan akan hal-hal yang mereka tidak mengerti dalam proses belajar mengajar, dari sisi inilah kita dapat memberikan petunjuk-petunjuk untuk mencari jawaban yang mereka butuhkan. Cara pembelajaran seperti ini bertujuan agar setiap murid yang kita ajarkan dapat memiliki insiatif yang tinggi dalam belajar serta membedakan mana yang benar dan mana yang salah, mencari solusi dari masalah yang mereka hadapi sehingga dapat menarik kesimpulan secara objektif. Untuk dapat mendidik murid kita berpikir kritis dan memiliki inisiatif dalam belajar, kita harus semaksimal mungkin merangsang daya pikir mereka, membangkitkan rasa penasaran di benak mereka sehingga menimbulkan keinginan untuk terus menggali solusi dari setiap persoalan yang ada dengan benar.

子曰: “不愤不启, 不悱不发。举一隅不以三隅反, 则不复也。”- 《论语・述 而》

Zì yuē: "bù fèn bù qĭ, bù fěi bù fā. Jǔ yī yú bù yǐ sān yú făn, zé bù fù yě." —— 《Lúnyǔ • Sù'ér》.

Dalam proses pencarian solusi itu, kita harus senatiasa untuk mendampingi murid kita. Pendampingan ini bertujuan untuk meminimalisasi kesalahan mereka dalam berpikir dan mengarahkan mereka kepada arah yang ingin kita capai.

Dari penjabaran di atas, setelah murid kita mendapatkan ilmu pengetahuan yang kita berikan, diharapkan tidak ada lagi kebingungan akan pemahaman ilmu pengetahuan yang telah mereka pelajari, hal ini dapat terlihat jelas dari kutipan berikut:

$$
\text { 子曰: “知者不惑, 仁者不忧, 勇者不惧。”《论语・子罕》 }
$$

Zǐ yuē: "zhī zhě bù huò rén zhě bù yōu, yǒng zhě bù jù." 《Lúnyǔ • Zǐ Hǎn》

Disebutkan bahwa orang yang berilmu tidak akan kebingungan tapi dapat membedakan mana yang baik dan mana yang buruk, sehingga sangat penting untuk melakukan pendampingan pembelajaran dengan menitikberatkan pemikiran yang kritis dan analitis.

Kita juga harus aktif untuk memberikan masukan dan mengkoreksi setiap kesalahan yang dibuat oleh murid kita. Hal ini juga sejalan dengan teori pengajaran Konfusius yang berbunyi:

$$
\text { 默而识之, 学而不厌, 诲人不倦, 何有于我哉?”- - 《论语・述而》 }
$$

mò ér zhì zhī, xué ér bù yàn, huì rén bù juàn, hé yǒu yú wǒz āi?" — - 《Lúnyǔ •Sù'ér》

Menekankan untuk selalu belajar dari setiap hal yang kita liat dan dengar serta tidak henti-hentinya untuk memperbaiki setiap kesalahan yang dibuat muridnya. Sebagai pengajar kita harus dapat menuntut diri kita dan murid kita untuk terus belajar, hal ini penting dikarenakan seiring dengan perkembangan zaman, ilmu pengetahuan juga akan terus berkembang sehingga kita tidak bisa untuk berhenti belajar dan memperbaharui ilmu kita. Selain itu, kita sebagai pengajar memiliki tanggung jawab dan membutuhkan kesabaran yang lebih dalam memperbaiki setiap kesalahan yang murid kita lakukan dan menuntut setiap mereka untuk dapat memperbaiki diri dan menghindari untuk melakukan kesalahan yang sama untuk kedua kalinya. 


$$
\begin{aligned}
& \text { 子日:“过而不改，是谓过矣。”- -《论语・卫灵公》， } \\
& \text { Zǐyuē: "guò ér bù găi, shì, wèi guò y̌i." - - 《Lúnyǔ•WèiLíngGōng》 }
\end{aligned}
$$

Bila kita melakukan kekeliruan, tetapi kita tidak mau mengubahnya maka kekeliruan itu akan menjadi kesalahan yang sebenarnya. Dalam kutipan di atas, ditekankan bahwa kita sebagai pengajar harus mengingatkan murid kita untuk memiliki kesadaran memperbaiki diri dan tidak melakukan pembiaran terhadap kesalahan yang telah dilakukan. Dari penjelasan di atas, kita dapat melihat bahwa dalam proses pembelajaran diperlukan proses evaluasi secara berkala untuk menghindari dan memperbaiki kesalahan-kesalahan yang tidak diperlukan.

Sesuatu hal yang baru tentu tidak akan mudah untuk dipelajari, adakalanya murid kita akan menemui kesulitan-kesulitan yang mungkin membuat mereka putus asa dan tidak mau mempelajarinya lebih lanjut, melalui kutipan berikut Konfusius mengajarkan kita sebagai pendidik untuk dapat memotivasi mereka untuk tetap berusaha walaupun menemui berbagai macam kesulitan dalam belajar,

$$
\text { 孔子日: “生而知之者上也, 学而知之者次也 }
$$

Kǒng Ž̀ yuē: "sheng ér zhī zhī zhě shàng yě,xué ér zhī zhī zhě cì yě

$$
\begin{aligned}
& \text { 困而学之, 又其次也; 困而不学, 民斯为下矣。”- - 《论语・季氏》 } \\
& \text { kùn ér xué zhī, yòu qí cì yè; kùn ér bù xué, mín sī wèi xià yǐ." - - 《Lúnyǔ • Jì Shì》 }
\end{aligned}
$$

Kutipan di atas Konfusius menjelaskan bahwa dalam mempelajari sesuatu pasti akan menemui kesulitan, dalam menghadapi kesulitan itu, kita harus tetap belajar karena jika dalam kesulitan itu kita memutuskan untuk tidak belajar maka itu akan menjadi sesuatu hal yang tidak baik untuk kita.

Sebagai pendidik pun kita harus bisa mengingatkan kepada murid kita akan pentingnya mengulang pembelajaran yang telah pernah dipelajarinya. Hal ini penting supaya mereka bisa memahami yang dipelajarinya dengan baik, tercermin dari kutipan buku Analek:

$$
\begin{aligned}
& \text { 子日:“学而时习之, 不亦说乎?”-—《论语・述而》 } \\
& \text { Zìyuē: “xué ér shí xí zhī, bù yì yuè hū?”- - 《Lúnyǔ • Súr 》 }
\end{aligned}
$$

yang menekankan bahwa mengulang sesuatu yang pernah dipelajari adalah sesuatu yang menyenangkan. Konfusius menitikberatkan akan adanya keteraturan dalam pembelajaran sehingga kita bisa menguasainya dengan baik, karena dari keteraturan ini lambat laun akan menjadi sebuah rutinitas kebiasaan yang memiliki nilai positif dalam menuntut ilmu. Selain itu, dengan kebiasaan kita mengulang pembelajaran yang telah kita dapatkan, diharapkan kita bisa untuk lebih mendalami ilmu yang telah kita pelajari. Dengan menerapkan sikap di atas juga secara tidak langsung kita sedang melatih diri kita membentuk karakter untuk hidup secara disiplin dan tidak sembarangan.

子日: “温故而知新, 可以为师矣。

Zǐ yue: "wēn gù ér zhī xīn, kěyǐ wéi shī yı̌. 
kutipan ini menjelaskan dengan seringnya mengulang hal yang pernah kita pelajari, diharapkan kita dapat menemukan hal yang baru dari yang pernah kita pelajari untuk dijadikan "guru" dalam mempelajari hal baru yang lainnya.

Mengulang sesuatu yang telah kita dipelajari sangat ditekankan oleh Konfusius, karena dengan sering mengulang kita dapat menguasai sesuatu dengan lebih baik lagi, sehingga setelah menguasainya kita dapat mengaplikasikannya dalam kehidupan kita sehari-hari, hal ini dapat dilihat dari kutipan lainnya,

$$
\begin{gathered}
\text { 曾子日: “.......... 传不习乎? ”-ー 《论语・学而》, } \\
\text { Zēngzi yuē: “...........chuán bù xí hū?” }- \text { 《Lúnyǔ • Xué'ér》 }
\end{gathered}
$$

kutipan ini menjelaskan bahwa sebagai pengajar kita harus dapat mengingatkan setiap murid kita untuk mengulang setiap hal yang telah kita ajarkan kepadamereka.

Dari hal-hal yang telah dibahas di atas, Konfusius juga menekankan akan pentingnya kontiunitas pembelajaran seperti yang disebutkan dalam kutipan berikut,

\section{子在川上曰：逝者如斯夫！不舍昼夜。”《论语・子罕》 Zì zài chuān shàng yuē: "shì zhě rú sĩ fú! bù shì zhòuyè." 《 Lúnyǔ • Zǐ Hăn》}

Dijelaskan melalui analogi yang diajarkan oleh Konfusius bahwa waktu akan berjalan seperti aliran air di sungai, siang malam akan terus mengalir tiada hentinya, kita dituntut untuk terus belajar tiada hentinya, karena pada dasarnya ilmu pengetahuan akan terus berkembang seiring dengan perkembangan waktu.

Selain sisi akademis yang Konfusius ajarkan kepada murid-muridnya, Konfusius juga mengajarkan etika untuk menjadi seorang pengajar yang baik.

$$
\begin{gathered}
\text { 子日:“有教 无类”-— 《论语・卫灵公》 } \\
\text { Zǐ yuē:“yǒu jiào wú lèi” }- \text { 《Lúnyǔ • WèiLíngGōng》 }
\end{gathered}
$$

Menerangkan bahwa dalam dunia pendidikan setiap orang berhak untuk mendapatkan ilmu yang mereka inginkan tanpa memandang status yang melekat pada diri mereka dan bersikap adil kepada mereka. Kutipan ini mengingatkan agar kita bisa memandang semua murid kita dengan setara, tanpa membeda-bedakan mereka, baik dalam transfer ilmu yang kita berikan kepada mereka, setiap penilaian dari sisi akademis maupun sisi non-akademis mereka. Hal ini penting agar murid kita selama menempuh pendidikan di perguruan tinggi bisa lulus dengan baik.

Pengajar yang baik harus dapat mempersiapkan semua hal-hal yang diperlukan dalam proses pembelajaran dengan baik karena tanpa persiapan yang optimal tentunya proses transfer ilmu pengetahuan yang ingin kita sampaikan akan berjalan kurang maksimal,

$$
\begin{aligned}
& \text { 子日: “工欲善其事, 必先 利其器。”《论语・卫灵公》 } \\
& \text { Zì yuē: “gong yù shàn qí shì, bì xiān lì qí qì.” 《Lúnyǔ • WèiLíngGōng》 }
\end{aligned}
$$

dalam kutipan di atas Konfusius menggunakan analogi untuk mengajarkan kita bahwa seorang pekerja untuk menghasilkan karya yang baik, hal utama yang harus disiapkan 
adalah peralatan kerjanya, analogi ini mengajarkan kita untuk selalu melakukan persiapan sebelum mengajar murid kita, karena adakalanya dengan segala kesibukan dan pengetahuan yang kita miliki, kita terkadang tidak melakukan persiapan mengajar dengan baik, sehingga dikhawatirkan murid kita yang menjadi korbannya dimana mereka tidak mendapatkan hasil pengajaran yang semestinya.

Selain itu, sebagai seorang pengajar kita juga harus bisa menjaga setiap perkataan maupun tindakan kita.

$$
\begin{gathered}
\text { 言必信, 行 必果- }- \text { 《论语・子路》 } \\
\text { yán bì xìn, xíng bì guǒ }- \text { 《Lúnyǔ • Zì Lù》 }
\end{gathered}
$$

Kutipan ini mengharuskan kita untuk dapat memegang setiap perkataan yang telah kita keluarkan dan juga kosistensi dari setiap tindakan yang kita lakukan. Konfusius menekankan hal ini karena sedikit banyak segala perkataan dan tindakan kita akan dijadikan panutan oleh murid kita, yang secara tidak langsung akan mencerminkan juga integritas kita sebagai seorang pengajar. Kita harus bisa menjadi teladan yang baik bagi setiap murid kita.

Dalam mempelajari sesuatu, baik pengajar maupun murid harus bisa mengutamakan akan aspek kejujuran, hal ini dapat dilihat dari kutipan berikut ini,

$$
\text { “知之为知之, 不知为不知, 是知也。”- 《论语・为政》, }
$$

zhī wéi zhī zhī, bù zhī wéi bù zhī, shì zhì yě." - - 《Lúnyǔ • Wéi Zhèng》

Yang berarti dalam mempelajari sesuatu kita harus bisa berlaku jujur dalam menuntut dan mempelajari suatu ilmu pengetahuan dan tidak berbohong dengan berpura-pura menguasainya. Jika dilihat lebih mendalam lagi, kutipan ini mengajarkan kita untuk dapat dengan rendah hati dalam menuntut ilmu dan setelah kita menguasainya kita harus tetap bersikap rendah hati dan tidak sombong serta mengajarkannya lagi kepada orang-orang yang membutuhkan.

Konfusius juga mengajarkan bahwa sebagai pengajar yang baik kitapun harus dapat mengasihi murid kita dengan sepenuh hati kita walau terkadang memerlukan usaha yang tidak sedikit untuk menuju ke arah situ, sehingga bagi kita yang mungkin terpanggil untuk mengabdi di bidang ini, kita mau tidak mau untuk terus melakukan tugas ini dengan sepenuh hati kita, seperti tersirat dalam kutipan ini,

$$
\text { 子日: 爱之, 能勿劳乎忠焉, 能勿诲乎? - - 《论语・为政》. }
$$

Zǐ yue: ài zhī, néng wù láo hū? zhōng yān, néng wù huì hū? - - 《Lúnyǔ • Wéi Zhèng》

Kutipan memiliki arti bahwa jika kita mengasihi murid kita, sebagai pengajar kita harus dapat mengajarkan dia untuk bekerja keras dan mengoreksi kesalahannya dengan cara yang benar.

Dari penjabaran di atas, dapat dilihat bahwa dalam pembelajaran Konfusius menekankan pentingnya tahapan yang harus dilakukan, dimulai dari melihat minat setiap murid kita, metode pengajaran yang digunakan, proses pembelajaran yang dilakukan sampai dengan pentingnya sikap setiap murid kita dalam pembelajaran itu sendiri, karena jika tidak demikian hasil pembelajaran yang dilakukan akan kurang efektif. 
Dibutuhkan usaha yang ekstra keras dari kita sebagai pengajar untuk bisa menghasilkan peserta didik yang berhasil, dari contoh-contoh penjelasan yang telah diberikan, kita bisa menerapkannya dalam pengajaran kita sehari-hari untuk membangkitkan kesadaran mereka tentang cara belajar yang baik, tidak lagi menjadikan pendidikan di perguruan tinggi sesuatu yang menakutkan tapi menjadikan hal itu sesuatu yang menyenangkan untuk dijalaninya.

Dalam pengajaran, ada baiknya kita dapat merancang sebuah sistem pembelajaran yang memperhatikan tingkat kemampuan dan minat dari masing-masing peserta didik kita, setelah itu kita dapat melakukan pendampingan yang membuat mereka untuk dapat berpikir secara mendalam dengan memberikan tugas dengan petunjuk-petunjuk yang membantu mereka untuk mendapatkan jawaban yang kita harapkan, setelah itu kita dapat melakukan pembahasan dan pembetulan dari setiap tugas yang telah mereka lakukan, kemudian kita dapat mengulang kembali apa yang telah mereka pelajari untuk membuat mereka lebih memahami materi yang kita ajarkan. Yang perlu ditekankan juga adalah efek yang harus mereka ketahui dari cara pembelajaran yang kita terapkan, hal ini penting agar mereka menyadari maksud dan tujuan yang ingin kita sampaikan, sehingga cara pembelajaran ini tidak menjadi rutinitas belaka tetapi dapat menjadi suatu kebiasaan yang bernilai positif dan bermanfaat bagi mereka.

\section{E. SIMPULAN}

Melalui pembahasan yang telah dilakukan dapat disimpulkan bahwa sebagai pendidik kita harus mengajarkan setiap murid kita agar memliki sikap belajar yang dibahas di atas, diharapkan kelak para peserta didik ini bisa menerapkannya ketika mereka terjun ke dunia kerja. Konfusius mengajarkan murid kita tidak hanya diajarkan hal-hal yang bersifat akademis tetapi juga mereka harus mendapatkan nilai lebih berupa pembentukan karakter dan kepribadian yang bertanggungjawab. Diharapkan mereka bisa menjadi seorang yang memiliki pemikiran yang kritis, sikap yang mau menerima masukan untuk memperbaiki kesalahan, disiplin, dan integritas yang baik.

\section{DAFTAR PUSTAKA}

[1] Bojun, Yang. 2009. Lunyu Yizhu. Beijing: Zhonghua Shuju.

[2] Bowu, Li. 2003. Guodian Chujian Yu Chu Wenhua. Hongkong: Guoji Yanhuang Wenhua Chuban She.

[3] Darini, Ririn. 2010. Pendidikan dalam Pemikiran Konfusius. Yogyakarta: Jurnal Pendidikan dan Ilmu Sejarah Istoria Vol. 7 No. 2.

[4] Halim, Steffi Thanissa; Christiana, Elisa \& Wijaya, Liejanto. 2014. Pemikiran Konfusius yang Terefleksi dalam Pengajaran Para Guru CHHS. Jakarta: Century Student E-Journal of Chinese Department.

[5] Huaixin, Huang. 2008. Lunyu Huijiao Jishi. Shanghai: Shanghai Guji Chuban She.

[6] Ikeda, Tomohisa. 2005. Mawangdui Hanmu Boshu Wu Xing Yanjiu. Beijing: Zhongguo Shehui Kexue Chuban She.

[7] Lindsey, Tim; Pausacker, Helen. 2005. Chinese Indonesians Remembering, Distorting, Forgetting. Singapore: Institutes of Southeast Asian Studies.

[8] Qipeng, Wei. 2005. Jianbo Wenxian Wu Xing Jianzheng. Beijing: Zhonghua Shuju.

[9] Shaoyu, Jiang. 2018. Lunyu Yandu. Shanghai. Zhongxi Shuju. 
[10] Tao, Liang. 2008. Guodian Zhujian Yu Meng Zi Xuepai. Beijing: Zhongguo Renmin Daxue Chuban She.

[10] Yuanzhi, Kong. 1999. Silang Budaya Tiongkok Indonesia. Jakarta: Bhuana Ilmu Populer. [12] Zhao, Liu. 2005. Guodian Chujian Jiaoshi. Fujian: Fujian Renmin Chuban She.

\section{DATA PENULIS}

Nama

: Yohan Yusuf Arifin, M.His.

Program studi : :D3 Bahasa Mandarin

Perguruan Tinggi : Universitas Kristen Maranatha

Telp.

: 081321902011

Email

:yohan.ya@yahoo.com 